Journal of Environmental Science and Sustainable Development

Volume 3

Issue 2 December

Article 9

$12-31-2020$

\title{
IMPACT OF EXCESSIVE PUMPING ON GROUNDWATER QUALITY: THE ARSENIC PROBLEM OF THE GANGES-MEGHNA-BRAHMAPUTRA DELTA IN SOUTHEAST ASIA
}

Rhitwik Chatterjee

State Water Investigation Directorate,West Bengal,India, rhitwikcu@yahoo.co.in

Mousumi Chowdhury

Indian Institute of Engineering Science and Technology, Shibpur,West Bengal,India, mousumichowdhury1988@gmail.com

Follow this and additional works at: https://scholarhub.ui.ac.id/jessd

Part of the Life Sciences Commons, and the Social and Behavioral Sciences Commons

\section{Recommended Citation}

Chatterjee, Rhitwik and Chowdhury, Mousumi (2020). IMPACT OF EXCESSIVE PUMPING ON GROUNDWATER QUALITY: THE ARSENIC PROBLEM OF THE GANGES-MEGHNA-BRAHMAPUTRA DELTA IN SOUTHEAST ASIA. Journal of Environmental Science and Sustainable Development, 3(2), 371-401. Available at: https://doi.org/10.7454/jessd.v3i2.1052

This Review Article is brought to you for free and open access by the School of Environmental Science at UI Scholars Hub. It has been accepted for inclusion in Journal of Environmental Science and Sustainable Development by an authorized editor of UI Scholars Hub. 


\title{
IMPACT OF EXCESSIVE PUMPING ON GROUNDWATER QUALITY: THE ARSENIC PROBLEM OF THE GANGES-MEGHNA-BRAHMAPUTRA DELTA IN SOUTHEAST ASIA
}

\author{
Rhitwik Chatterjee $^{1 *}$, Mousumi Chowdhury ${ }^{2}$ \\ ${ }^{1}$ State Water Investigation Directorate, West Bengal, India \\ ${ }^{2}$ Indian Institute of Engineering Science and Technology, Shibpur, West Bengal, India \\ *Corresponding author: rhitwikcu@yahoo.co.in
}

(Received: 11 August, 2020; Accepted: 23 December 2020; Published: 31 December 2020)

\begin{abstract}
This review of the impact of large-scale pumping on arsenic distribution reveals that groundwaterfed irrigation and domestic withdrawal impart tremendous stress on the limited groundwater resource base and disrupts the dynamic equilibrium of the groundwater system of the GangesMeghna-Brahmaputra (GMB) delta in Southeast Asia. Excessive groundwater extraction through pumping affects the groundwater quality in three major ways. First, excessive pumping transports atmospheric oxygen and organic-rich surface water to the subsurface. Second, it promotes arsenic build up in surface soil irrigated with arsenic-laced groundwater. Finally, it shifts groundwater replenishment zones lying at various depths near extraction points, thus, carrying dissolved arsenic from shallow Holocene paleo-channel aquifers to deeper paleo-channel aquifers of the Pleistocene age. Optimal management for safe and sustainable groundwater exploitation operations in the area must aim to ameliorate the deleterious impacts of pumping on groundwater quality through either technological or policy intervention.
\end{abstract}

Keywords: Arsenic; Groundwater; Ganges-Meghna-Brahmaputra (GMB) delta; Irrigation.

\section{Introduction}

The 21st century is replete with problems related to human sustainability. However, the global water crisis is gradually overriding other problems related to health and sanitation, climate change, food security, industrial growth, and/or energy production. The multi-faceted problem of global water shortage has left parts of the global population suffering for water and the rest suffering from water. Excessive groundwater withdrawal has significantly increased the water stress in over $60 \%$ of the world, especially in Africa, Latin America, and Asia. In Southeast Asia, the availability of water resources is further limited by quality issues. According to the WWAP (2003) and Morris et al. (2003), most of the population in developing nations is vulnerable to either anthropogenically or geogenic ally polluted water and prone to water-borne diseases. This situation is particularly problematic for developing nations due to the dearth of proper institutional and structural DOI: https://doi.org/10.7454/jessd.v3i2.1052 
arrangements for the treatment of contaminated water, which greatly impairs the livelihood of economically underprivileged populations.

The global pattern of the distribution of freshwater resources available for biological consumption is extremely limited. Groundwater comprises the largest distributed store of freshwater available for human-sustaining ecosystems. In general, water is considered a finite natural resource. Approximately50\% of the global population uses groundwater for drinking (Coughanowr 1994), and over 65\% of the groundwater withdrawals from the subsurface is due to irrigation (FAO 2005). Approximately $25 \%$ of the world's total irrigated land is fed by subsoil water, and $75 \%$ of them are in Asia (Shah et al., 2007; Shamsudduha et al., 2011). The United Nations Food and Agricultural Organization estimated that, by 2025, 1.9 billion people will likely face acute water scarcity and two-thirds of the global population will be confronted with water stress (Bandyopadhyay 2015). Indiscriminate pumping of groundwater resources in the pursuit of food security is believed to be responsible for this issue. The ingress of saline water in coastal aquifers, subsidence of land, and loss of ecological fidelity through the drying of surface water bodies warrant serious attention and are linked to the deleterious impacts of indiscriminate pumping (Budhu \& Adiyaman, 2010; Chai et al., 2004; Don et al., 2006; Erban etal.,2014; Essink, 2001; Feyen \& Gorelick, 2005; Folch et al., 2011; Ghassemi et al.,1995; Ripl, 1992; Wang et al., 2008; Werner et al., 2012; Wright and Berrie, 1987; Zektser et al., 2005).

However, studies encompassing the impacts of pumping on groundwater quality are scarce. Contemporary research reveals that overexploitation of subsoil water from shallow aquifers results in not only significant decreases in groundwater volume to levels below sustainable limits but also mobilization of toxic geogenic contaminants, such as arsenic and fluoride, from soil to water and their eventual spread to biotic systems through the food chain (Acharyya,2000; Bhattacharya et al.,1997; Biswas et al., 2012; Chakraborty et al.,2015; Das et al., 1996; Dowling et al., 2002; Kamra, Lal, Singh, \& Boonstra, 2002; McArthur et al., 2004; Michael \& Voss, 2008; Mukherjee et al., 2007; Pal et al., 2002; Ravenscroft et al., 2005). At present, the mechanisms through which pumping affects water quality amidst complex hydrogeological conditions are incompletely understood. The present work intends to pinpoint such mechanisms from the perspective of existing scholarly and gray literature, with focus on the arsenic problem of the Ganges-MeghnaBrahmaputra (GMB) delta in Southeast Asia. 


\subsection{Magnitude of the problem}

The intensive use of groundwater in agriculture has caused serious debates in many parts of the world after the introduction of inexpensive drilling technology in the early 20th century, especially after the 1950s. The global scale of groundwater abstraction soared from 100-150 km ${ }^{3}$ in 1950 to 950-1000 $\mathrm{km}^{3}$ in 2000. The agricultural sector of Asia plays a pivotal role in the remarkable increase of these numbers. The complex interplay of supply-push factors (e.g., easy availability of low-cost pumps and drilling technologies to pastoralists, government subsidies) and demand-pull factors(e.g., on-demand irrigation to support wealth-generating agro-practices, immunity from climatic externalities) has promoted massive increases in groundwater extraction (FAO 2005).In the Indian subcontinent, the use of groundwater grew from approximately $10-20 \mathrm{~km}^{3}$ in 1949 to 240 $260 \mathrm{~km}^{3}$ in 2000 (Kumar \& Shah, 2006). Overexploitation occurs when withdrawal surpasses the natural recharge for an extensive area over a long period of time (Alley et al., 2007; Konikow \& Kenedy, 2005). Tweed et al. (2018) revealed that groundwater depletion is prolific in semi-arid and humid regions of the globe.

This finding implies that the effects of climate-related changes on recharge rates are minimal compared with those of non-climatic factors (Bates et al., 2008; Kundzewicz et al., 2007; Wemer \& Gleeson, 2012).The relative ease of access to subsoil water has led to the overexploitation of global groundwater resources (Sikdar et al., 2001; Mukherjee et al., 2007; Pfeiffer \& Lin, 2012). Overexploitation may deplete river basins to the point where native aquatic flora and fauna are unable to survive (Loáiciga, 2004; Rains, 2003).Incidents have been reported in rivers, such as the Carmel River (Central Coast) and the Colorado River in the Colorado Desert (USA), and major regions of South and Central Asia, the Middle East, Northern China (Taihang Mountains), Australia, and North America (Tularam \& Krishna, 2009). India and Mexico (Alto Rio Lerma Irrigation District, Guanajuato, Mexico) (Salazar et al., 2005; Scot \& Shah, 2004) are among the leading groundwater users in the world and face severe overdraft challenges. Up to $25 \%$ of India's agriculture has been affected by the shortage of groundwater resources (Tularam \& Krishna, 2009). Besides these countries, California in the Southwestern United States, Iran, and many African countries, such as Tanzania and Cape Town in South Africa, has also become vulnerable to overdraft problems (Konikow, 2005; Schmidt, 2007; Villholth, 2013; Zektser et al., 2005). As the groundwater resource is depleted, the quality of the water obtained has also deteriorated.

The quality of groundwater is governed by the chemical properties of rainwater, mineralogy and geochemistry of soils and the sediment matrix, and duration of contact between the water and these soil and aquifer materials. Groundwater quality is gradually deteriorating because of the entry of 
contaminants into the aqueous environment through human or natural activities from point and nonpoint sources. Point sources refer to those related to urban development (e.g., underground storage tanks [hydrocarbons], landfills, intensive rural industries [nitrates], cattle and sheep dips [pesticides], manufacturing spills, mining-related activities [heavy metals, acid, hydrocarbons]), while nonpoint sources refer to those normally found in nature (e.g., intense application of fertilizers and pesticides for agricultural, automobile emissions in urban areas) (Ball, 2007). The problem of water quality deterioration due to excessive groundwater abstraction goes hand in hand with the issues of aquifer depletion.

According to Liu et al. (2003), groundwater extraction allows the transport of dissolved oxygen (in recharge water) to the subsurface; the oxygen oxidizes immobile minerals, thereby releasing toxicants, such as arsenic, into the groundwater. Raquela et al. (2006) reported that subsurface waters pumped from fertilized agricultural lands in Mexico contain inappropriate levels of toxic materials. Chirenjea et al. (2007) reported similar incidents from the Kirkwood Cohansey Aquifer System in New Jersey (USA). According to Chakroborty et al., (2015), the arsenic in the Bengal Basin may originate from deep-seated tectono-magmatism in the Himalayan Orogenic belt, which transports the element to the surface. Subsequent sedimentary processes transport arsenic-laced sediments to the Bengal Basin where, under suitable biogeochemical triggers, the toxicant is released to the groundwater system. Multiple processes (e.g., reductive dissolution of metal oxides and hydroxides, redox cycling in surficial soils, competitive ion exchange), individually or simultaneously, may be responsible for the subsequent release of lethal metalloids. The processes of such release are significantly complicated by redox disequilibrium in Bengal Basin aquifers and anthropogenic intervention through pumping. Thus, the source of arsenic in the GMB delta is mostly geogenic in nature, and excessive pumping barely aggravates its mobilization processes.

Singh and Sheriff (2002) reported that approximately 137 million dwellers in over70 countries across5 continents are exposed to arsenic contamination in drinking water. This problem is especially acute in South Asian countries, such as Bangladesh, Eastern India, Cambodia, and Vietnam (Fazal et al., 2001; Postma et al., 2007; Stute et al., 2007; Van Geen et al., 2006). Sengupta et al., (2003) described the mass poisoning in Bangladesh aseven deadlier than the disasters of Bhopal, in India(1984), and Chernobyl, in the Ukraine(1986).The major alluvial and deltaic plains and inland basins of South and East Asia, such as the Bengal Basin of Bangladesh and eastern India, the Yellow River plain, and some internal basins of northern China, the lowland Terai region of Nepal (Gurung et al., 2005), Mekong Valley of Cambodia, the Red River delta of Vietnam, and the Irrawaddy delta of Myanmar, are vulnerable to groundwater arsenic problems. 
Unfortunately, all these areas are flat-lying fertile plains composed of young sediments and often densely populated. The growing incidence of arsenic poisoning in these areas follows the pattern of change in the agro-practice of using groundwater from tube wells instead of dug wells, which began in $1970-1980$.

Prior to India's independence, its economy was challenged by many famines, the most severe of which was the Bengal famine in 1943 that killed three million; this figure is equal to the number of persons who perished during the Nazi holocaust. In 1947-1960, the government of India adopted a "grow more food" campaign and implemented an intensive agriculture development program as an ameliorative measure. Subsequently, the government embraced the "Green Revolution" as a response to the crisis in food production. The Green Revolution came along with chemical agriculture and an increase in the rate of application of nitrogenous fertilizers and pesticides. However, while all these practices have helped India achieve new heights of production capacity in the agriculture sector; the existing agro-ecosystems have also been adversely affected.

Soil fertility loss, soil erosion, soil toxicity, diminishing water resources, subsoil water pollution, and underground water salinity are some of the negative impacts of the widespread adoption of improved agricultural technologies by farmers to ensure the success of the Green Revolution. The unabated pumping of groundwater resulted in a significant drop in the groundwater level below the sustainable limit, which, in turn, paved the way for the mobilization of toxic geogenic contaminants, such as arsenic and fluoride, from soil to water and their eventual spread to biotic systems through the food chain. The number of toxicity incidents in India today is spreading at an alarming rate. The available data show that, among 593 districts in India, 203 suffer from fluoride contamination, 206 from iron contamination, 137 from high salinity, 109 from nitrate contamination, and 35 from arsenic poisoning (DDWS 2006). A summary of the available data describing the magnitude of the drinking water quality problem in India is presented in Tables 1 and 2.

The scale of the groundwater crisis is increasing in major proportions of the country; thus, assessing the existing knowledge to identify the longer-term effects of groundwater pumping on water quality and describe the mechanism of the relevant interaction process is appropriate. However, groundwater abstraction is a physical process that imparts specific effects on contaminants depending on their geochemical behavior. In this work, the authors review the current understanding of the arsenic contamination of the GMB region of the Indo-Gangetic Basin (IGB) by using the existing scholarly and gray literature. 
Table 1. Estimated Order of Magnitude (Districts and Populations Affected) and Impact of Drinking Water Quality Issues in India

\begin{tabular}{|c|c|c|c|c|}
\hline $\begin{array}{l}\text { Quality } \\
\text { Problems }\end{array}$ & $\begin{array}{l}\text { Number } \\
\text { of } \\
\text { Districts }\end{array}$ & $\begin{array}{c}\text { Estimated } \\
\text { Population } \\
\text { Affected/Exposed }\end{array}$ & Cause & Impact \\
\hline Salinity & 137 & $\begin{array}{l}\text { Estimates not } \\
\text { available }\end{array}$ & $\begin{array}{l}\text { Geogenic/Man-made } \\
\text { (coastal saline intrusion due } \\
\text { to over pumping) }\end{array}$ & $\begin{array}{l}\text { Kidney stones } \\
(\text { Cost/family=7500per/day })\end{array}$ \\
\hline Fluoride & 203 & 65 million & $\begin{array}{l}\text { Geogenic but aggravated } \\
\text { also by Overexploitation; } \\
\text { increased by malnutrition }\end{array}$ & $\begin{array}{l}\text { Fluorosis } \\
(\text { Cost/capita }>5000 / y r)\end{array}$ \\
\hline Arsenic & 35 & $\begin{array}{l}5 \text { million in West } \\
\text { Bengal; even more } \\
\text { but un-estimated in } \\
\text { Assam, Bihar }\end{array}$ & $\begin{array}{l}\text { Complex geogenic process } \\
\text { not yet well understood; but } \\
\text { suspected to be related to } \\
\text { excessive water table } \\
\text { fluctuation }\end{array}$ & $\begin{array}{l}\text { Arsenicosis }(\mathrm{DALY}=5-27 \\
\text { per } 1000 \text { population) }\end{array}$ \\
\hline Iron & 206 & $\begin{array}{l}\text { Estimates } \\
\text { available }\end{array}$ & Mainly geogenic & $\begin{array}{l}\text { Cirrhosis, suspected } \\
\text { diarrhea, cardiac linkages }\end{array}$ \\
\hline Biological & $\begin{array}{l}\text { Estimates } \\
\text { not } \\
\text { available }\end{array}$ & $\begin{array}{l}\text { Estimates } \\
\text { available }\end{array}$ & $\begin{array}{l}\text { Poor sanitation and hygiene, } \\
\text { malnutrition }\end{array}$ & $\begin{array}{l}\text { Diarrhea; } \\
\text { million/yr }\end{array}$ \\
\hline $\begin{array}{l}\text { Agro- } \\
\text { chemicals }\end{array}$ & $\begin{array}{l}\text { Estimates } \\
\text { not } \\
\text { available }\end{array}$ & $\begin{array}{l}\text { Estimates } \\
\text { available }\end{array}$ & $\begin{array}{ll}\text { Related } & \text { to } \\
\text { pesticide/fertilizer use in } \\
\text { agriculture }\end{array}$ & $\begin{array}{l}\text { Multiple impacts; not } \\
\text { understood well }\end{array}$ \\
\hline $\begin{array}{l}\text { Industrial } \\
\text { effluents }\end{array}$ & $\begin{array}{l}\text { Estimates } \\
\text { not } \\
\text { available }\end{array}$ & $\begin{array}{l}\text { Estimates } \\
\text { available }\end{array}$ & $\begin{array}{l}\text { Due to effluents from } \\
\text { industries }\end{array}$ & $\begin{array}{l}\text { Multiple impacts; not } \\
\text { understood well }\end{array}$ \\
\hline
\end{tabular}

Source: Susheela (1999)

\section{Methods}

Groundwater is a crucial source of drinking water to millions across the globe. The World Bank (1998) reported that, in India, groundwater accounts for $80 \%$ of the domestic water needs in rural areas and $50 \%$ of the water demand in urban areas. Selecting the GMB delta, which is part of the IGB, as the region of focus in this review is valid for several reasons. The IGB represents a vital terrestrial water system encompassing 250 million hectares of land, approximately 100 million of 
which is arable, across Bangladesh, India, Pakistan, and southern Nepal; the region is inhabited by a population of nearly 750 million and supported by $25 \%$ of the global groundwater irrigation (Benner \& Fendrof, 2010). The IGB forms the largest fluvio-deltaic system in the world (Akter et al., 2016; Alam \& Sattar, 2000; Coleman, 1981; Gupta, 2007; Mukherjee et al., 2007) in terms of $\operatorname{area}\left(123.5 \times 10^{3} \mathrm{~km}^{2}\right)$ and annual sediment discharge $\left(>1 \times 10^{9} \mathrm{t} / \mathrm{yr}\right)$ (Bandyopadhyay 2007) hoisting about 2 of the global population within an area of $\sim 200,000 \mathrm{~km}^{2}$ and covers the eastern regions of West Bengal and most of Bangladesh. It is situated within the Bengal Basin of South Asia (Goodbred \& Nicholls, 2004; Khandoker, 1987; Morgan \& William, 1959; Sarker et al., 2003) in front of the Himalayan foredeep, within the catchment areas of the GBM Rivers between Bangladesh and India, and just above the Bay of Bengal.

Table 2. Extent of Drinking Water Vulnerability in India

\begin{tabular}{|c|c|c|c|}
\hline Description & $\begin{array}{l}\text { Number of } \\
\text { Districts }\end{array}$ & $\begin{array}{c}\text { Percentage of } \\
\text { Total } \\
\text { Districts }\end{array}$ & Major States \\
\hline $\begin{array}{l}\text { High Level of } \text { Groundwater } \\
(\mathrm{GWD}>70 \%) \text { Development } \\
\text { ("Unsafe" Districts) }\end{array}$ & 178 & 30 & $\begin{array}{l}\text { Punjab, Haryana, Rajasthan, UP, } \\
\text { Gujrat, Tamil Nadu }\end{array}$ \\
\hline $\begin{array}{l}\text { GWD }<70 \% \text { but with quality } \\
\text { problems - Fluoride }\end{array}$ & 128 & 22 & Rajasthan, Gujrat, MP, Karnataka \\
\hline $\begin{array}{l}\text { GWD }<70 \% \text { but with quality } \\
\text { problems - Arsenic }\end{array}$ & 40 & 7 & WB, Karnataka, Maharashtra \\
\hline $\begin{array}{l}\text { GWD }<70 \% \text { but with quality } \\
\text { problems - Nitrate }\end{array}$ & 62 & 11 & $\begin{array}{l}\text { Assam, Gujrat, Maharashtra, } \\
\text { Rajasthan, Kerala }\end{array}$ \\
\hline $\begin{array}{l}\text { GWD }<70 \% \text { but with quality } \\
\text { problems - Salinity }\end{array}$ & 80 & 14 & $\begin{array}{l}\text { Assam, Haryana, Kerala, Gujrat, } \\
\text { Rajasthan, Orissa }\end{array}$ \\
\hline $\begin{array}{l}\text { GWD }<70 \% \text { but with quality } \\
\text { problems - Iron }\end{array}$ & 175 & 30 & $\begin{array}{l}\text { Assam, Bihar, Chhattisgarh, Kerala, } \\
\text { Orissa }\end{array}$ \\
\hline Biological contamination & No clear dat & a available & \\
\hline $\begin{array}{l}\text { At least one of the three most } \\
\text { serious quality problems } \\
\text { (Arsenic/fluoride/salinity) }\end{array}$ & 169 & 29 & $\begin{array}{l}\text { Assam, Gujrat, Haryana, Karnataka, } \\
\text { Maharashtra, MP, Orissa, Rajasthan, } \\
\text { UP, WB }\end{array}$ \\
\hline
\end{tabular}




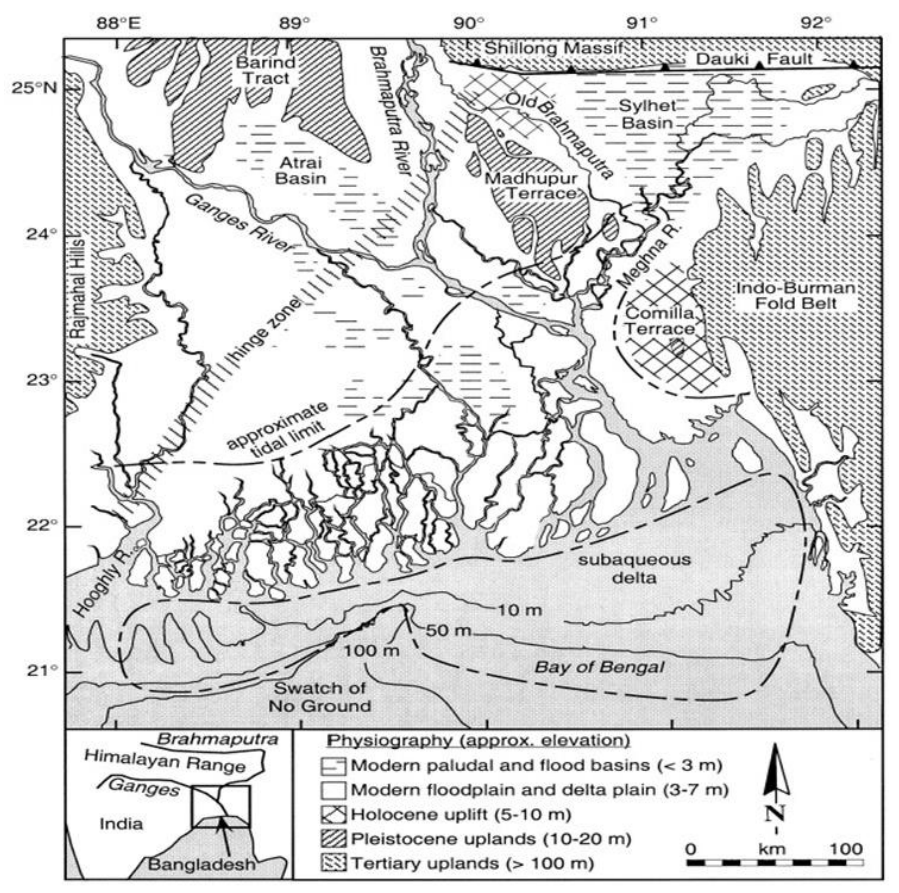

Figure 1. Regional map of Bengal Basin showing the physiography and geology of the Ganges-Meghna-Brahmaputra delta and surrounding area

Source: Goodbred et al. (2003)

The delta is an extremely fertile and intensely vegetated alluvial land; it is often called the "Green Delta" (Islam, 2016). The role of groundwater is extremely vital in this area; it provides drinking water for urban and rural communities and is a key resource for food grain production. Unfortunately, besides its extensive use of groundwater, the region is also known for arsenic contamination within shallow aquifer systems (Anawar et al., 2003; Benner \& Fendorf, 2010; Chakroborti et al.,2001; McArthur et al., 2004; Mukherjee, 2007; Ravenscroft et al., 2005; Sengupta et al.,2003).Subsoil water circulating within these shallow aquifer systems is generally abstracted by individual pastoralists for their livelihood (Shah et al., 2007). However, contemporary researchers have determined that irrigation using arsenic-laden water has led to yield losses and arsenic transfer to the human system via the food chain (Bhattacharyya et al., 1997; Cubadda et al., 2010; Dittmar et al., 2007; Duxbury et al.,2003; Farooq et al., 2010; Punshon et al.,2017). Arsenic pollution is especially evident to the east of the Bhagirathi River and major parts of Bangladesh within aquifers composed of Holocene lowland, organic-rich, fine sand to silt and clayey sediments.

The agrarian economy of this area depends largely on agriculture, and its development requires the expansion of irrigation facilities. In particular, the cultivation of dry-season Boro-rice (Harvey et al., 2006; Mukherjee 2008) has accelerated the demand for irrigation. Consequently, millions of 
wells, including light duty hand-pumped wells to heavy-duty motor driven ones, have been installed to cater to increasing water demands. At present, approximately25\% (McArthur et al., 2004) to 33\% (Honerman et al., 2004; Mukherjee, 2006) of these wells have become contaminated with arsenic. Recent hydrogeological studies by Rodell et al. (2009), Shamsudduha et al. (2009), and Tiwari et al. (2009) have shown reductions in aquifer storage due to unsustainable groundwater abstraction to meet both irrigation and urban water demands in these areas. The deleterious impacts of intensive groundwater abstraction at the regional scale have been reported by several authors (Alley et al., 2002; Alley \& Leake, 2004; Sophocleous, 2000). Harvey et al. (2006), Klump et al. (2006), Neumann et al. (2009), and Stute et al. (2007), indicated that heavy irrigational pumping is responsible for the regional-scale perturbation of the shallow groundwater system. However, Bredehoeft (2002) recently reported that large-scale pumping may augment groundwater recharges by either diverting riverine water or increasing the available aquifer storage throughout the dry season, thereby increasing recharge during the subsequent wet (i.e., monsoon) season (MPO 1987). Regional scale groundwater flow modeling by Michael and Voss (2009a) in the Bengal Basin supports this view. However, in both cases, the factual impact of the large-scale pumping of groundwater-on-groundwater quality warrants a careful review (Shamsudduha et al., 2011).

\section{Results and Discussion}

Arsenic-bearing minerals originating from the Himalayan orogeny are carried and stored in Bengal Basin sediments through riverine erosion by the Ganges, Brahmaputra, and Meghna Rivers (Guillot et al., 2007). The arsenic is mobilized into the groundwater system under suitable geochemical conditions and brought to the surface during prolific irrigation pumping in the delta. This arsenic is then stored in the topsoil of the region, spread over the basin, and recirculated back into the groundwater system through irrigation return flow. In general, groundwater is less prone to contamination than surface water. Moreover, the impurities present in rainwater, which replenishes dynamic groundwater resources, are naturally removed over the course of soil infiltration.

Irrigated farming and the disposal of industrial effluents on surface water bodies are responsible for augmenting groundwater quality issues. Temporal changes in groundwater quality may be invoked by the pumping of different quanta of water with varied chemistry from one or multiple geologic strata (Keith et al., 1983; Nightingale and Bianchi, 1980; Schmidt, 1977; Whittemore et al., 1989; Wilson and Rouse, 1983).It may induce recharge from proximal sources. If such sources contain elevated levels of arsenic, then the otherwise safer portions of the aquifer may be contaminated. For example, the eastern segment of Chakdah City, in Nadia District, West Bengal, 
is in the floodplain of the Hooghly River. Here indiscriminate extraction of groundwater through a public supply well resulted in the contamination of a shallow aquifer, which subsequently attracted a nearby arsenic plume to the subsurface (Charlet et al., 2007).

Seasonal changes in the flow direction of groundwater impart a vertical shift, and excessive groundwater extraction perturbs the balance and promotes a change in the distribution pattern of dissolved arsenic through mixing effects (Neidhardt et al., 2013). The hydraulic conductivity in the Bengal Basin is generally considered an isotropic, with greater values in the horizontal direction than in the vertical one (Michael \& Voss, 2009a). The flat topography of the Bengal delta plain (BDP)imparts an extremely low flow velocity. Thus, the region is highly vulnerable to anthropogenic pumping, which perturbs the natural hydro-chemical conditions and arsenic distributions (Michael \& Voss, 2009b). Because the BDP sediments conform toa single and massive hydraulically interconnected aquifer system, extensive groundwater extraction can further impart the drawdown of arsenic-laced shallow groundwater into deeper aquifers if not protected by locally ensemble aquitards or buried paleosols (Mc Arthur et al., 2011; Michael \& Voss, 2009a; Michael \& Voss, 2009b).Pumping may also modify the direction of groundwater flow at a local scale to interconnect diverse redox zones within an aquifer and trigger arsenic mobilization and adsorption into local aquifer sediments.

Kinniburgh et al. (1994) studied the effect of long-term groundwater abstraction on the deterioration of water quality at the Basal and Chalk aquifers of north London; the authors opined that the closed-system oxidation of pyrite amid subsurface environments by primarily air-saturated groundwater is insufficient to give rise to remarkably elevated concentrations of $\mathrm{SO}_{4}$ in pore water; instead, anomalous concentrations of $\mathrm{SO}_{4}$ in the pore water indicate that the degree of oxidation is controlled by the availability of areal oxygen rather than the input of dissolved oxygen or nitrate present within the groundwater or recharge water itself. Abstraction from the Chalk aquifer over many decades has resulted in the dewatering of the overlying Basal Sands aquifer and the concomitant entry of air into the subsoil, which ultimately leads to the localized oxidation of pyrite, where the rate of oxidation is highest near the bore wells, and the accumulation of poor-quality porewater in the Basal Sands. A similar mechanism was proposed by advocates of the pyrite oxidation hypothesis (Acharyya, 2000; Chowdhury et al., 1999; Das et al., 1996; Kittrick, Fanning, \& Hossner, 1982; Mallick \& Rajagopal, 1996; Mandal et al.,1996) for arsenic release within the groundwaters of the Bengal Basin. 


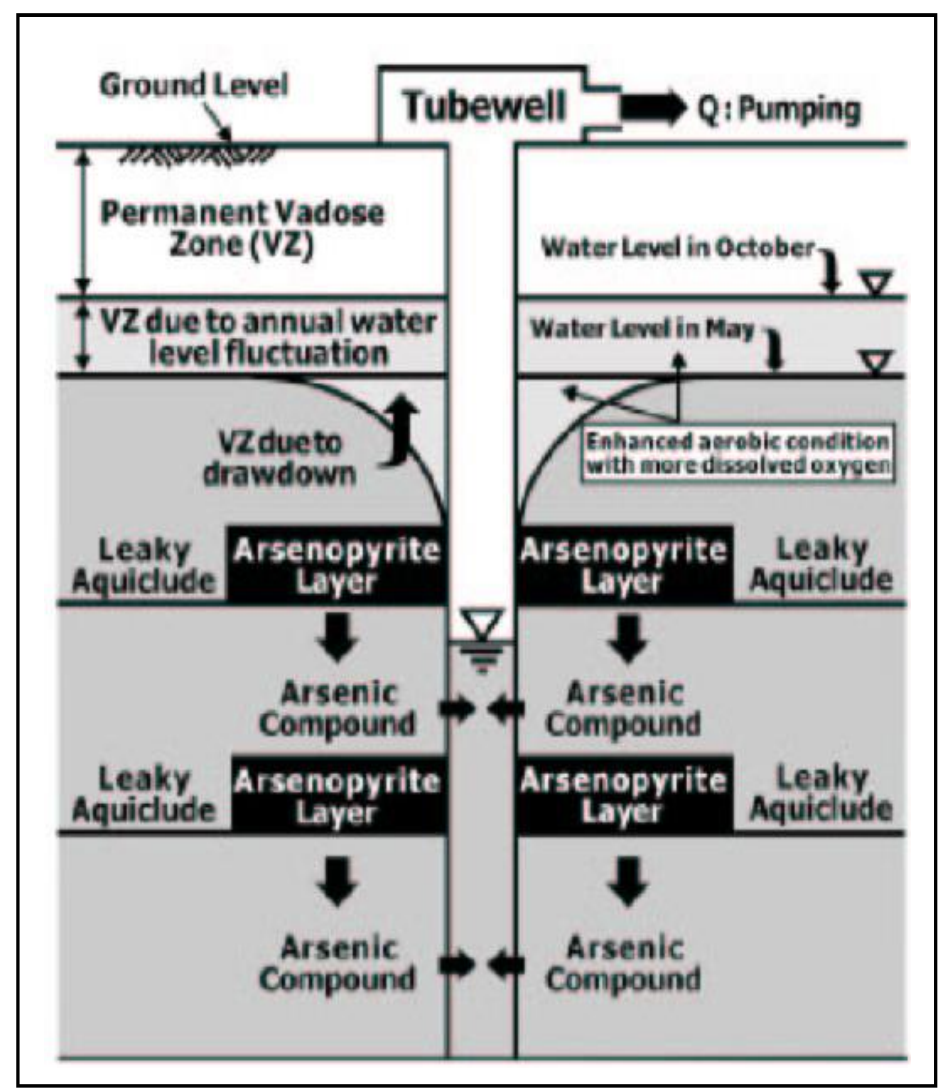

Figure 2. Mechanism of arsenic releaseinto the GMB delta sediment according to pyrite oxidation hypothesis

Source: Adopted from Mallick and Rajagopal (1996)

Arsenic is taken up by certain insoluble sulfide minerals that are co-deposited with the Holocene anoxic gray aquifer sediments of the BDP. The pumping-induced decrease in the water table beneath such deposits exposes them to atmospheric oxygen and lead to the oxidation of pyrite grains in the vadose zone into soluble sulfate, thus releasing soluble arsenate $\left(\mathrm{As}^{3+}\right)$, sulfate $\left(\mathrm{SO}^{2-}{ }_{4}\right)$, and ferrous iron $\left(\mathrm{Fe}^{2+}\right)$ to the groundwater. Mukherjee et al. (2011) argued that enhanced groundwater recharge due to increased discharge resulting from unabated pumping creates avenues for increased inflow and the deeper permeation of dissolved oxygen into the reducing aquifers.

$$
\mathrm{Fe} \mathrm{AsS}+13 \mathrm{Fe}^{3+}+8 \mathrm{H}_{2} \mathrm{O} \longrightarrow 14 \mathrm{Fe}^{2+}+\mathrm{SO}^{2-}{ }_{4}+13 \mathrm{H}^{+}+\mathrm{H}_{3} \mathrm{AsO}_{4}(\mathrm{aq})
$$

This hypothesis, albeit a breakthrough in the history of arsenic research, was rejected by many scholars because of the absence of pyrite in the affected aquifer sediments and low concentration of sulfur in the affected groundwater. However, the impact of pumping on groundwater quality is quite clear. 
Harvey et al. (2002) and Polya and Charlet (2009)described an inverse relation between arsenic and sulfate concentrations in the pore waters of the Holocene aquifers in Bangladesh. The authors proposed that large-scale irrigation pumping may aggravate arsenic concentrations by drawing surface water enriched in highly reactive organic compounds below ground (Graham et al., 2015). This water fuels the microbially mediated reduction of arsenic-bearing iron minerals and the simultaneous release of arsenic from the solid phase to the groundwater. According to them, during the dry season, irrigational abstraction is done in havoc quantity; the water collected is later replaced by monsoonal rains and local surface water. The infiltrating surface water contains high concentrations of dissolved carbon because they come from paddy fields and organic-rich pond and river sediments and could change the water chemistry in a manner that may trigger arsenic release from the sediments.

Recent research has revealed that irrigation using arsenic-polluted water adds sufficient arsenic to soils, which is detrimental for sustainable agricultural production in South and Southeast Asian countries (Heikens, 2006; Williams et al., 2006). The concentrations of solid-phase arsenic in soils is usually greater (as high as $40 \mu \mathrm{g} / \mathrm{g}$ at the surface in Bangladesh) than that in aquifer sediments (Meharg et al., 2003; Polizzotto et al., 2006; Swartz et al., 2012), which may be due, at least in part, to the irrigational return flow of groundwater (Meharg \& Rahman, 2003). According to Xie et al. (2012), extensive leaching from irrigation return flow is probably the dominant process behind the spread of arsenic in groundwater. Groundwater undergoes seasonal changes in redox conditions, from irrigation to non-irrigation periods, with the reducing environment being prolonged during the non-irrigation period. Arsenic is released rampantly through the reduction of iron oxides/hydroxides and oxidation of iron sulfides during the irrigation period and retained in the soil even during the non-irrigation period (Xie et al., 2015).

Since the early 1970s, irrigational pumping has been practiced at a large scale in Bangladesh and West Bengal (CGWB, 1994; Mukherjee et al., 2007), thus exposing the anoxic groundwater from the aquifers to areal oxygen; arsenic was subsequently sequestered into the oxidized ferric iron in the agricultural fields (BADC, 1992; Roychowdhury et al., 2005). The arsenic content of the soil zone of rice fields in the Bengal Basin have accumulated up to the order of $1 \mathrm{~kg} / \mathrm{ha} / \mathrm{yr}$. This arsenic may be subsequently recirculated into the groundwater, thus contributing to the contamination problem (Chakraborti et al., 2001; Mukherjee et al., 2007; Ravenscroft et al., 2005). Ali et al. (2003) assessed that, during the irrigation season, approximately $27209 \mathrm{Mm}^{3}$ of groundwater (considering an average discharge of 101/s and 1200 hours of irrigation each season) is pumped out. Such extensive abstraction of arsenic-laden water from shallow aquifers adds large quantities of 
arsenic (approximately1 $\mathrm{kg}$ of arsenic per hectare of irrigated land each year) to the agro-fields annually via irrigation water. Another approximately46 metric tons of arsenic is extracted every year from the subsoil water through domestic tube wells in Bangladesh. Overall, over900metric tons of arsenic is cycled each year through groundwater in Bangladesh. This arsenic is then subjected to the soil-water-plant environment, where they may be (i) transformed through microbially mediated redox processes, (ii) volatilized into the atmosphere through various biological processes, (iii) undergo adsorption-desorption to become retained on soil surface, washed through surface runoff, or leached to the groundwater, and (iv) transported into the food chain through plant uptake.

Arsenic accumulation over soil surfaces is most common in the case of rice (paddy) fields, where the topsoil is maneuvered to hold water on the surface. Large quantities of water ( $1000 \mathrm{~mm} / \mathrm{crop})$ are used to irrigate rice, where arsenic is mainly present as As (III), under reducing conditions. In this form, the arsenic is most readily available to plant roots (Ali et al., 2003; Brammer \& Ravenscroft 2009). In irrigated agricultural land, evaporation leaves arsenic behind, along with other minerals, on the topsoil, where it is retained for a while on account of its affinity for iron, manganese, aluminum, and other minerals in soil under toxic conditions. Even flood or rainwater is unable to wash this deposit away, resulting the accumulation of arsenic in surface soils to levels as high as $83 \mathrm{mg} / \mathrm{kg}$ in topsoil (Alam \& Sattar, 2000; Huq, Ahmed, Suktana, \& Naidu, 2001; Ullah, 1998). Most of this accumulation in irrigated agricultural fields is found within the top 150-200 $\mathrm{mm}$ of soil. In Bangladesh, arsenic concentrations appear to be $10 \mathrm{mg} / \mathrm{kg}$ over non-irrigated floodplain soils (Abedin et al. 2002) and are like or lower in the topsoil than in the subsoil (Saha \& Ali, 2006).Topsoil arsenic levels in irrigated areas may reach $>10 \mathrm{mg} / \mathrm{kg}$ (Duxbury \& Zavala, 2005). Huq et al. (2001) reported arsenic levels of $>20 \mathrm{mg} / \mathrm{kg}$, with a maximum of $81 \mathrm{mg} / \mathrm{kg}$, in the same layer. The safe limit of arsenic for paddy field soils generally lies in the range of $25-50 \mathrm{mg} / \mathrm{kg}$ (Duxbury \& Panaullah, 2007; Saha \& Ali, 2006). However, actual soil loading rates may vary with the amount of irrigation water applied, arsenic concentrations in the water, and losses due to evaporation, crop removal, and leaching.

After contaminant loading in the topsoil, the arsenic is further translocated to the biosphere from the pedosphere through plant/crop uptake. The degree of arsenic uptake by plants varies among plant species and is governed by soil characteristics, such asfertility, and the concentration and chemical forms of arsenic in soil (Punshon et al.,2017). Arsenic is present as As (V) in solid-phase oxidized soils. Therefore, in such soils, arsenic in the groundwater used for irrigation is quickly adsorbed, retained by iron hydroxides, and rendered unavailable for plant uptake (Brammer \& 
Ravenscroft, 2009). In anaerobic soils, arsenic occurs as As (III) and is readily dissolved in the soil porewater, where it is easily available for plant uptake through roots (Xu et al., 2008).

Van Geen et al. (2006) held that irrigating rice fields/crops with arsenic-laced groundwater could be lethal and specified two significant consequences of arsenic build up on topsoil, namely, reduced crop yields and arsenic exposure through ingestion of contaminated soil (Abedin et al., 2002b; Duxbury et al., 2003). According to the authors, the alarmist view of arsenic spread from rice may patronize the exploitation of deeper aquifers, which are presently low in arsenic, and, in turn, entrain arsenic-laden water from shallow aquifers into deeper ones, leading to their contamination (Zheng et al.,2005).

Sikdar et al. (2018) attempted to assess the possibility of arsenic transport from the shallow paleo-channel (SPC) Holocene aquifer to the deep aquifer of the Late Pleistocene through deep pumping. According to the authors, prolific irrigation, and domestic abstraction over a sustained period of time from deep aquifers (depth $>70 \mathrm{~m} \mathrm{bgl}$ ) may draw arsenic-contaminated water from the SPC aquifer and into the deep paleo-channel (DPC) Holocene aquifer but not any further. Thus, arsenic in the Late Pleistocene groundwater beneath the DPC originates from some local sources and not from the overlying arsenic contaminated SPC aquifer.

Radloff et al. (2011) suggested that groundwater with elevated arsenic concentrations may be commonly found within the top 100m of aquifer systems in South and Southeast Asia. However, in the case of West Bengal and Bangladesh, groundwater at depths greater than $150 \mathrm{~m}$ is considered arsenic safe. Recent surveys of deep $(>150 \mathrm{~m})$ hand-pumped wells have shown that approximately $14 \%-18 \%$ of the wells in Bangladesh and $25 \%$ of those in the four most contaminated districts of West Bengal contain arsenic at concentrations well beyond the limit of toxicity. Groundwater flow simulations have suggested that deep waters are at risk of contamination due to replenishment with high-arsenic groundwater from above, even when deep aquifer pumping is restricted to domestic use.

Megacities impart enormous benefits to the global economy; however, large heavily populated urban areas may strain water resources (Howard \& Gelo, 2002). Urban and industrial development imposes a major threat to water resources through increased demands. Development not only releases contaminants to the subsurface but has also exploits deep aquifers to meet domestic and industrial needs. Heavy pumping of the groundwater under urban hotspots may alter the hydrological system. A study carried out by Sikdar and Chakrabory (2008) indicated that groundwater abstraction may potentially alter the natural flow pattern of an area;future high 
groundwater abstraction may drive arsenious water horizontally within the aquifer toward freshwater zones along with downward infiltration.

Sahu et al. (2013) carried out a study on the East Calcutta Wetlands and revealed that heavy pumping of groundwater has altered the hydrological system of flat deltaic regions because of their low topographic gradient. The study also indicated that, under the current pumping scenario of Kolkata City, additional recharge areas may be created in the North 24-Parganas, South 24Parganas, and Howrah districts as recharge areas migrate toward pumping centers. Unfortunately, these newly formed recharge zones are already being heavily contaminated with arsenic; some experts estimate that the polluted water may reach the depth of the city aquifer within 40 years.

\section{Conclusion}

The unabated development of large-scale irrigated agriculture in Southeast Asia has created heavy demands on its limited groundwater supplies, especially over the last few decades. The central theme of the current conflict involves the depletion of groundwater without a compensatory recharge to the aquifers. However, for dwellers of the GMB delta, the problem of quality degradation of the precious groundwater resource is even more acute than the plummeting water table. Declines in well yield caused by depleted resource base may exacerbate the gap between the competitive and optimal modes of water use. While advanced water-efficient technologies may be adopted to ameliorate this issue, water quality degradation is an irreversible outcome of aquifer trade-offs.

The effects of intensive groundwater extraction on water quality have rarely been subject to direct reviews through experimentation and/or simulation studies but area central theme in many scholarly debates and gray literature. Recent findings based on regional-scale hydrological modeling have shown that abstraction may foster groundwater recharge during the monsoon season, which casts some doubt on the alarmist assertion. Thus, can groundwater abstraction activities be encouraged without limitation or prejudice in the name of food and other allied economic security? The answer is a profound no because pumping exerts deleterious effects on water quality. Future water management policies should, therefore, embrace the dynamic nature of groundwater and consider not only the spatiotemporal responses of water levels in the abstraction scenario but also water quality issues to promote the sustainable use of groundwater resources in the GMB delta. 


\section{Author Contribution}

Rhitwik Chatterjee conceived and presented the idea. The literature survey has been conducted by Rhitwik Chatterjee, jointly with Mousumi Chowdhury. Both the authors discussed the results and contributed to the final manuscript.

\section{References}

Abedin, M. J., Cotter-Howells, J., \& Meharg, A. A. (2002). Arsenic uptake and accumulation in rice (Oryza sativa L.) irrigated with contaminated water. Plant and soil, 240(2), 311319.https://doi.org/10.1023/A:1015792723288

Abedin, M. J., Cresser, M. S., Meharg, A. A., Feldmann, J., \& Cotter-Howells, J. (2002). Arsenic accumulation and metabolism in rice (Oryza sativa L.). Environmental science \& technology, 36(5), 962-968.https://doi.org/10.1021/es0101678

Acharyya, S. K., Lahiri, S., Raymahashay, B. C., \& Bhowmik, A. (2000). Arsenic toxicity of groundwater in parts of the Bengal basin in India and Bangladesh: the role of Quaternary stratigraphy and Holocene sea-level fluctuation. Environmental Geology, 39(10), 1127-1137.

Akter, J., Sarker, M. H., Popescu, I., \& Roelvink, D. (2016). Evolution of the Bengal Delta and its prevailing processes. Journal of Coastal Research, 32(5), 1212-1226.

Alam, M. B., \& Sattar, M. A. (2000). Assessment of arsenic contamination in soils and waters in some areas of Bangladesh. Water Science and Technology, 42(7-8), 185-192. https://doi.org/10.2166/wst.2000.0568

Ali, M. A., Badruzzaman, A. B. M., Jalil, M. A., Hossain, M. D., Ahmed, M. F., Masud, A. A., \& Rahman, M. A. (2003). Fate of arsenic extracted with groundwater. Fate of Arsenic in the Environment, 7-20.

https://pdfs.semanticscholar.org/7da2/40c21abc72b2afcc28993d796bb729e3ba45.pdf

Alley, W. M., \& Leake, S. A. (2004). The journey from safe yield to sustainability. Groundwater, 42(1), 12-16.

https://doi.org/10.1111/j.1745-6584.2004.tb02446.x

Alley, W. M., Healy, R. W., La Baugh, J. W., \& Reilly, T. E. (2002). Flow and storage in groundwater systems. Science, 296(5575), 1985-1990.

https://doi.org/10.1126/science.1067123

Alley, W. M., Reilly, T. E., Franke, O. L. (2007). Effects of ground water development on ground water flow to and from surface water bodies.

http://pubs.usgs.gov/circ/circ1186/html/gw_effect.html 
Anawar, H. M., Akai, J., Komaki, K., Terao, H., Yoshioka, T., Ishizuka, T., ... \& Kato, K. (2003). Geochemical occurrence of arsenic in groundwater of Bangladesh: sources and mobilization processes. Journal of Geochemical Exploration, 77(2-3), 109-131. https://doi.org/10.1016/S0375-6742(02)00273-x

BADC (1992). Deep Tubewell II Project. Final Report. Mott MacDonald Ltd. And Hunting Technical Services. Report for Bangladesh Agricultural Development Corporation and Overseas Development Administration (UK) Vol2.1. www.badc.gov.bd

Bandyopadhyay, N. (2015). Groundwater pollution a great threat to mankind. Journal of Centre for Groundwater Studies,46(IV). http://www.cgwskolkata.com/groundwater-journal.html

Bandyopadhyay, S. (2007). Evolution of the Ganga Brahmaputra delta: a review. Geographical review of India, 69(3), 235-268.

http://www.academia.edu/download/32170836/Geogr_Rev_Ind_69(3)_2007_Bandyopadhya y_GBD_Evolution.pdf

Bates, B., Kundzewicz, Z., \& Wu, S. (2008). Climate change and water. Intergovernmental Panel on Climate Change Secretariat. http://www.taccire.suanet.ac.tz:8080/xmlui/handle/123456789/552

Benner, S. G., \& Fendorf, S. (2010). Arsenic in south Asia groundwater. Geography Compass, 4(10), 1532-1552. https://doi.org/10.1111/j.1749-8198.2010.00387.x

Bhattacharya, P., Chatterjee, D., \& Jacks, G. (1997). Occurrence of arseniccontaminatedGroundwater in alluvial aquifers from Delta plains, eastern India: options for safe drinking water supply. International Journal of Water Resources Development, 13(1), 79-92. https://doi.org/10.1080/07900629749944

Biswas, A., Nath, B., Bhattacharya, P., Halder, D., Kundu, A. K., Mandal, U., ...\& Jacks, G. (2012). Hydrogeochemical contrast between brown and grey sand aquifers in shallow depth of Bengal Basin: consequences for sustainable drinking water supply. Science of the Total Environment, 431, 402-412. https://doi.org/10.1016/j.scitotenv.2012.05.031

Brammer, H., \& Ravenscroft, P. (2009). Arsenic in groundwater: a threat to sustainable agriculture in South and South-east Asia. Environment International, 35(3), 647-654. https://doi.org/10.1016/j.envint.2008.10.004

Bredehoeft, J. D. (2002). The water budget myth revisited: why hydrogeologists model. Groundwater, 40(4), 340-345.

https://ngwa.onlinelibrary.wiley.com/doi/abs/10.1111/j.1745-6584.2002.tb02511.x 
British Geological Survey, \& Mott MacDonald International Ltd. (1999). Groundwater Studies for Arsenic Contamination in Bangladesh: Main report (Vol. 1). British Geological Survey. https://www.bgs.ac.uk/

Budhu, M., \& Adiyaman, I. B. (2010). Mechanics of land subsidence due to groundwater pumping. International journal fornumerical and analytical methods in geomechanics, 34(14), 1459-1478.https://doi.org/10.1002/nag.863

CGWB. (1994). Hydrogeological atlas of West Bengal. Scale 1:2,000,000Eastern Region Government of India.http://wbwridd.gov.in/swid/mapimages/FINAL_WB.pdf

Chai, J. C., Shen, S. L., Zhu, H. H., \& Zhang, X. L. (2004). Land subsidence due to groundwater drawdown in Shanghai. Geotechnique, 54(2), 143-147. https://doi.org/10.1680/geot.2004.54.2.143

Chakraborti, D., Basu, G. K., Biswas, B. K., Chowdhury, U. K., Rahman, M. M., Paul, K., ... \& Ray, S. L. (2001). Characterization of arsenic bearing sediments in Gangetic delta of West Bengal-India. Arsenic exposure and health effects. New York: Elsevier Science, 27-52.

Chakraborty, M., Mukherjee, A., \& Ahmed, K. M. (2015). A review of groundwater arsenic in the Bengal Basin, Bangladesh and India: from source to sink. Current Pollution Reports, 1(4), 220-247.https://doi.org/10.1007/s40726-015-0022-0

Charlet, L., Chakraborty, S., Appelo, C. A. J., Roman-Ross, G., Nath, B., Ansari, A. A., ... \& Mallik, S. B. (2007). Chemodynamics of an arsenic "hotspot" in a West Bengal aquifer: a field and reactive transport modeling study. Applied Geochemistry, 22(7), 12731292.https://doi.org/10.1016/j.apgeochem.2006.12.022

Chirenje, T., Epstein, C., \& Mueller, R. (2007). Water quality issues in the outer coastal plains: New Jersey. Developments in Environmental Science, 5, 561-589. https://doi.org/10.1016/S1474-8177(07)05026-7

Chowdhury, T. R., Basu, G. K., Mandal, B. K., Biswas, B. K., Samanta, G., Chowdhury, U. K., \& Roy, S. (1999). Arsenic poisoning in the Ganges delta. Nature, 401(6753), 545-546. https://doi.org/10.1038/44056

Coleman, J. M. (1981). Deltas: processes and models of deposition for exploration: Minneapolis. Minnesota, Burgess, CEPCO Division, 124. https://books.google.co.id/books/about/Deltas.html?id=TysAxQEACAAJ\&redir_esc=y

Coughanowr, C. (1994). Ground water. Water-Related Issues of the Humid Tropics and Other Warm Humid Regions. IHP Humid Tropics Programme. Serie No8. UNESCO. https://www.ircwash.org/resources/ihp-humid-tropics-programme-series 
Cubadda, F., Ciardullo, S., D’Amato, M., Raggi, A., Aureli, F., \& Carcea, M. (2010). Arsenic contamination of the environment- food chain: A survey on wheat as a test plant to investigate phytoavailable arsenic in Italian agricultural soils and as a source of inorganic arsenic in the diet. Journal of agricultural and food chemistry, 58(18), 10176-10183. https://doi.org/10.1021/jf102084p

Das, D., Samanta, G., Mandal, B. K., Chowdhury, T. R., Chanda, C. R., Chowdhury, P. P., Basu, G. K., \& Chakraborti, D. (1996). Arsenic in groundwater in six districts of West Bengal, India. Environ Geochem Health, 18(1), 5-15. https://doi.org/10.1007/BF01757214

DDWS. (2006). Summary of nation-wise statistics from Rajiv Gandhi drinking water mission. New Delhi: Department of Drinking Water Resources, Govt. of India. http://mowr.gov.in/

Dittmar, J., Voegelin, A., Roberts, L. C., Hug, S. J., Saha, G. C., Ali, M. A., ... \& Kretzschmar, R. (2007). Spatial distribution and temporal variability of arsenic in irrigated rice fields in Bangladesh. 2. Paddy soil. Environmental Science \& Technology, 41(17), 5967-5972.

Don, N. C., Hang, N. T. M., Araki, H., Yamanishi, H., \& Koga, K. (2006). Groundwater resources and management for paddy field irrigation and associated environmental problems in an alluvial coastal lowland plain. Agricultural water management, 84(3), 295-304. https://doi.org/10.1016/j.agwat.2006.03.006

Dowling, C. B., Poreda, R. J., Basu, A. R., Peters, S. L., \& Aggarwal, P. K. (2002). Geochemical study of arsenic release mechanisms in the Bengal Basin groundwater. Water Resources Research, 38(9), 12-1. https://doi.org/10.1029/2001WR000968

Duxbury, J. M. (2007). Remediation of arsenic for agriculture sustainability, food security and health in Bangladesh. http://www.fao.org/3/a-ap102e.pdf

Duxbury, J. M., \& Zavala, Y. J. (2005, January). What are safe levels of arsenic in food and soils. In Behavior of arsenic in aquifers, soils and plants (Conference Proceedings), International Symposium, Dhaka.

Duxbury, J. M., Mayer, A. B., Lauren, J. G., \& Hassan, N. (2003). Food chain aspects of arsenic contamination in Bangladesh: effects on quality and productivity of rice. Journal of Environmental Science and Health, Part A, 38(1), 61-69. https://doi.org/10.1081/ESE120016881

Erban, L. E., Gorelick, S. M., \& Zebker, H. A. (2014). Groundwater extraction, land subsidence, and sea-level rise in the Mekong Delta, Vietnam. Environmental Research Letters, 9(8), 084010. https://iopscience.iop.org/article/10.1088/1748-9326/9/8/084010/meta 
Essink, G. H. O. (2001). Improving fresh groundwater supply-problems and solutions. Ocean \& Coastal Management, 44(5-6), 429-449. https://doi.org/10.1016/S0964-5691(01)00057-6

FAO (Food and Agriculture Organization). (2005). AQUASTAT database.

www.fao.org/ag/agl/aglw/aquastat/main/index.stm

Farooq, S. H., Chandrasekharam, D., Berner, Z., Norra, S., \& Stüben, D. (2010). Influence of traditional agricultural practices on mobilization of arsenic from sediments to groundwater in Bengal delta. Water research, 44(19), 5575-5588.

https://doi.org/10.1016/j.watres.2010.05.057

Fazal, M. A., Kawachi, T., \& Ichion, E. (2001). Extent and severity of groundwater arsenic contamination in Bangladesh. Water International, 26(3), 370-379. https://doi.org/10.1080/02508060108686929

Feyen, L., \& Gorelick, S. M. (2005). Framework to evaluate the worth of hydraulic conductivity data for optimal groundwater resources management in ecologically sensitive areas. Water Resources Research, 41(3). https://doi.org/10.1029/2003WR002901

Folch, A., Menció, A., Puig, R., Soler, A., \& Mas-Pla, J. (2011). Groundwater development effects on different scale hydrogeological systems using head, hydrochemical and isotopic data and implications for water resources management: The Selva basin (NE Spain). Journal of Hydrology, 403(1-2), 83-102. https://doi.org/10.1016/j.jhydrol.2011.03.041

Ghassemi, F., Jakeman, A. J., \& Nix, H. A. (1995). Salinisation of land and water resources: human causes, extent, management and case studies. $C A B$ international. https://www.cabdirect.org/cabdirect/abstract/19976767459

Goodbred Jr, S. L. (2003). Response of the Ganges dispersal system to climate change: a source-tosink view since the last interstade. Sedimentary Geology, 162(1-2), 83-104. https://www.sciencedirect.com/science/article/abs/pii/S0037073803002173

Graham, P. W., Baker, A., \& Andersen, M. S. (2015). Dissolved organic carbon mobilisation in a groundwater system stressed by pumping. Scientific Reports, 5, 18487. https://doi.org/10.1038/srep18487

Guillot, S., \& Charlet, L. (2007). Bengal arsenic, an archive of Himalaya orogeny and paleohydrology. Journal of Environmental Science and Health, Part A, 42(12), 1785-1794. https://doi.org/10.1080/10934520701566702

Gupta, A. (2007). Large rivers geomorphology and Management. United Kingdom: Chichester, Wiley 689p. 
Gurung, J. K., Ishiga, H., \& Khadka, M. S. (2005). Geological and geochemical examination of arsenic contamination in groundwater in the Holocene Terai Basin, Nepal. Environmental Geology, 49(1), 98-113. https://doi.org/10.1007/s00254-005-0063-6

Harvey, C. F., Ashfaque, K. N., Yu, W, Badruzzaman, A. B. M., Ali, M. A., Oates, P. M. .. \& Ahmed, M. F. (2006) Groundwater dynamics and arsenic contamination in Bangladesh. Chemical Geology,228(1-3), 112-136. https://doi.org/10.1016/j.chemgeo.2005.11.025

Harvey, C. F., Swartz, C. H., Badruzzaman, A. B. M., Keon-Blute, N., Yu, W., Ali, M. A., ...\& Oates, P. M. (2002). Arsenic mobility and groundwater extraction in Bangladesh. Science, 298(5598), 1602-1606. https://doi.org/10.1126/science.1076978

Heikens, A. (2006). Arsenic contamination of irrigation water, soil and crops in Bangladesh: Risk implications for sustainable agriculture and food safety in Asia. RAP Publication (FAO). http://agris.fao.org/agris-search/search.do?recordID=XF2007429249

Honerman, A., van Geen, A., Kent, D. V., Mathe, P. E., Zheng, Y., Dhar, R. K., .. \& Seddique, A. A. (2004). Decoupling of As and Fe release to Bangladesh groundwater under reducing conditions. Part I: Evidence from sediment profiles. Geochimica et Cosmochimica Acta, 68(17), 3459-3473. https://doi.org/10.1016/j.gca.2004.01.026

Howard, K. W. F., \& Gelo, K. K. (2002). Intensive groundwater use in urban areas: the case of megacities. Intensive use of groundwater: challenges and opportunities, 484. http://pubs.usgs.gov/circ/circ1186/html/gw_effect.html

Huq, S. I., Ahmed, K. M., Suktana, N., \& Naidu, R. (2001). Extensive arsenic contamination of groundwater and soils of Bangladesh. In Arsenic in the Asia Pacific Region Workshop, Adelaide, Managing Arsenic for the Future (Vol. 94).

Islam, S. N. (2016). Deltaic floodplains development and wetland ecosystems management in the Ganges-Brahmaputra-Meghna Rivers Delta in Bangladesh. Sustainable Water Resources Management, 2(3), 237-256. https://doi.org/10.1007/s40899-016-0047-6

Kamra, S. K., Lal, K., Singh, O. P., \& Boonstra, J. (2002). Effect of pumping on temporal changes in groundwater quality. Agricultural Water Management, 56(2), 169-178. https://doi.org/10.1016/S0378-3774(02)00004-5

Karim, M. M., Komori, Y., \& Alam, M. (1997). Subsurface arsenic occurrence and depth of contamination in Bangladesh. Journal of Environmental Chemistry, 7(4), 783-792. https://doi.org/10.5985/jec.7.783 
Keith, S. J., Wilson, L. G., Fitch, H. R., \& Esposito, D. M. (1983). SOURCES OF SPATIAL-TEMPORAL VARIABILITY IN GROUNDWATER QUALITY DATA AND METHODS OF CONTROL: This case study of the Cortaro, Arizona, monitoring program discusses controlling or accommodating sources of variability. Groundwater Monitoring \& Remediation, 3(2), 21-32. https://doi.org/10.1111/j.1745-6592.1983.tb01196.x

Khandoker, R. A. (1987). Origin of elevated Barind-Madhupur areas, Bengal basin: result of neotectonic activities. Bangladesh Journal of Geology, 6(2), 1-9.

https://www.scirp.org/(S(i43dyn45teexjx455qlt3d2q))/reference/ReferencesPapers.aspx?Refe renceID $=17443$

Kinniburgh, D. G., Gale, I. N., Smedley, P. L., Darling, W. G., West, J. M., Aldous, P. J., \& O'Shea, M. J. (1994). The effects of historic abstraction of groundwater from the London Basin aquifers on groundwater quality. Applied Geochemistry, 9(2), 175-195. https://doi.org/10.1016/0883-2927(94)90006-X

Kittrick, J. A., Fanning, D. S., Hossner, L. R. (1982). Aqueous pyrite oxidation and the consequent formation of secondary iron minerals. Acid Sulfate Weathering, 10, 37-56. https://acsess.onlinelibrary.wiley.com/doi/abs/10.2136/sssaspecpub10.c3

Klump, S., Kipfer, R., Cirpka, O. A., Harvey, C. F., Brennwald, M. S., Ashfaque, K. N., ... \& Imboden, D. M. (2006). Groundwater dynamics and arsenic mobilization in Bangladesh assessed using noble gases and tritium. Environmental Science \& Technology, 40(1), 243250. https://doi.org/10.1021/es051284w

Konikow, L. F. (2005) Ground Water Depletion across the Nation. USGS. http://pubs.usgs.gov/fs/fs-103-03/

Konikow, L. F., \& Kendy, E. (2005). Groundwater depletion: A global problem. Hydrogeology Journal, 13(1), 317-320. https://doi.org/10.1007/s10040-004-0411-8

Kulkarni, H., \& Shankar, P. V. (2009). Groundwater: towards an aquifer management framework. Economic and Political Weekly, 13-17.

https://www.epw.in/journal/2009/06/commentary/groundwater-towards-aquifer-managementframework.html

Kumar, M. D., \& Shah, T. (2006). Groundwater pollution and contamination in India: the emerging challenge. IWMI-TATA Water Policy Program Draft Paper, 1, 14. https://www.researchgate.net/profile/Prabhat_Ranjan14/post/Should_people_pay_for_polluti ons_imparted_by_them/attachment/59d6410779197b807799d23c/AS:433345634017280@14 80329058323/download/ground-pollute4_FULL_.pdf 
Kundzewicz, Z. W., Mata, L. J., Arnell, N. W., Doll, P., Kabat, P., Jimenez, B., ... \& Shiklomanov, I. (2007). Freshwater resources and their management. In: Parry, M. L., Canziani, O. F., Palutikof, J. P., van der Linden, P. J. and Hanson, C. E. (eds.) Climate Change 2007: Impacts, Adaptation and Vulnerability. Contribution of Working Group II to the Fourth Assessment Report of the Intergovernmental Panel on Climate Change. Cambridge University Press, pp. 173-210. ISBN 9780521880091. http://centaur.reading.ac.uk/1017/

Langseth, P., \& Stapenhurst, R. (2012). India-Water resources management sector review: groundwater regulation and management report. Agriculture \& Rural Development (SASDA). http://agris.fao.org/agris-search/search.do?recordID=US2012418595

Lenntech. (1993). Seawater intrusions in groundwater. Netherlands: The Technical University of Delft. http://www.lenntech.com/About-Lenntech.htm

Liu, C. W., Lin, K. H., \&Kuo, Y. M. (2003). Application of factor analysis in the assessment of groundwater quality in a blackfoot disease area in Taiwan. Science of the Total Environment, 313(1-3), 77-89. https://doi.org/10.1016/S0048-9697(02)00683-6

Loáiciga, H. A. (2004). Analytic game-theoretic approach to ground-water extraction. Journal of Hydrology, 297(1-4), 22-33. https://doi.org/10.1016/j.jhydrol.2004.04.006

Mallick, S., \& Rajagopal, N. R. (1996). Groundwater development in the arsenic-affected alluvial belt of West Bengal-some questions. Current Science, 70(11), 956-958. https://www.jstor.org/stable/24111630

Mandal, B. K., Chowdhury, T. R., Samanta, G., Basu, G. K., Chowdhury, P. P., Chanda, C. R., ...\& Das, D. (1996). Arsenic in groundwater in seven districts of West Bengal, India-the biggest arsenic calamity in the world. Current science, 70(11), 976-986. https://www.jstor.org/stable/24111635

McArthur, J. M., Banerjee, D. M., Hudson-Edwards, K. A., Mishra, R., Purohit, R., Ravenscroft, P., ...\& Lowry, D. (2004). Natural organic matter in sedimentary basins and its relation to arsenic in anoxic ground water: the example of West Bengal and its worldwide implications. Applied Geochemistry, 19(8), 1255-1293. https://doi.org/10.1016/j.apgeochem.2004.02.001

McArthur, J. M., Nath, B., Banerjee, D. M., Purohit, R., \& Grassineau, N. (2011). Palaeosol control on groundwater flow and pollutant distribution: the example of arsenic. Environmental Science \&Technology, 45(4), 1376-1383. https://doi.org/10.1021/es1032376 
Meharg, A. A., \& Rahman, M. M. (2003). Arsenic contamination of Bangladesh paddy field soils: implications for rice contribution to arsenic consumption. Environmental Science \&Technology, 37(2), 229-234. https://doi.org/10.1021/es0259842

Michael, H. A., \& Voss, C. I. (2008). Evaluation of the sustainability of deep groundwater as an arsenic-safe resource in the Bengal Basin. Proceedings of the National Academy of Sciences, 105(25), 8531-8536. https://doi.org/10.1073/pnas.0710477105

Michael, H. A., \& Voss, C. I. (2009a). Controls on groundwater flow in the Bengal Basin of India and Bangladesh: regional modeling analysis. Hydrogeology Journal, 17(7), 1561. https://doi.org/10.1007/s10040-008-0429-4

Michael, H. A., \& Voss, C. I. (2009b). Estimation of regional-scale groundwater flow properties in the Bengal Basin of India and Bangladesh. Hydrogeology Journal, 17(6), 1329-1346.

Morgan, J. P., \& McINTIRE, W. G. (1959). Quaternary geology of the Bengal basin, East Pakistan and India. Geological Society of America Bulletin, 70(3), 319-342. https://doi.org/10.1130/0016-7606(1959)70\%5b319:QGOTBB\%5d2.0.CO;2

Morris, B. L., Lawrence, A. R., Chilton, P. J. C., Adams, B., Calow, R. C., \&Klinck, B. A. (2003). Groundwater and its susceptibility to degradation: a global assessment of the problem and options for management (Vol. 3). United Nations Environment Programme. http://nora.nerc.ac.uk/id/eprint/19395/

MPO (Master Plan Organization). (1987). Groundwater resources of Bangladesh. Technical Report no. 5. Master Plan Organization/Hazra/Sir M MacDonald/Meta/EPC, Dhaka/USA/UK/USA/Bangladesh.

https://www.scirp.org/(S(lz5mqp453edsnp55rrgjct55))/reference/ReferencesPapers.aspx?Refere nceID $=1650362$

Mukherjee, A. (2008). Deeper groundwater flow and chemistry in the arsenic affected western Bengal basin, West Bengal, India. Applied Geochemistry, 23(4), 863-894. https://doi.org/10.1016/j.apgeochem.2007.07.011

Mukherjee, A., Fryar, A. E., \& Howell, P. D. (2007). Regional hydrostratigraphy and groundwater flow modeling in the arsenic-affected areas of the western Bengal basin, West Bengal, India. Hydrogeology Journal, 15(7), 1397. https://doi.org/10.1007/s10040-007-02087

Mukherjee, A., Fryar, A. E., \& Thomas, W. A. (2009). Geologic, geomorphic and hydrologic framework and evolution of the Bengal basin, India and Bangladesh. Journal of Asian Earth Sciences, 34(3), 227-244. https://doi.org/10.1016/j.jseaes.2008.05.011 
Mukherjee, A., Fryar, A. E., Scanlon, B. R., Bhattacharya, P., \& Bhattacharya, A. (2011). Elevated arsenic in deeper groundwater of the western Bengal basin, India: Extent and controls from regional to local scale. Applied Geochemistry, 26(4), 600-613. https://doi.org/10.1016/j.apgeochem.2011.01.017

Negri, D. H. (1989). The common property aquifer as a differential game. Water Resources Research, 25(1), 9-15. https://doi.org/10.1029/WR025i001p00009

Neidhardt, H., Berner, Z., Freikowski, D., Biswas, A., Winter, J., Chatterjee, D., \& Norra, S. (2013). Influences of groundwater extraction on the distribution of dissolved As in shallow aquifers of West Bengal, India. Journal of Hazardous Materials, 262, 941-950.

https://doi.org/10.1016/j.jhazmat.2013.01.044

Neumann, R. B., Ashfaque, K. N., Badruzzaman, A. B. M., Ali, M. A., Shoemaker, J. K., \& Harvey, C. F. (2010). Anthropogenic influences on groundwater arsenic concentrations in Bangladesh. Nature Geoscience, 3(1), 46-52. https://doi.org/10.1038/ngeo685

Nicholls, R. J.\& Goodbred, S. L. (2004). Towards integrated assessment of Ganga-Brahmaputra delta, $5^{\text {th }}$ International Conference on Asian Marine Geology. https://eprints.soton.ac.uk/53186/

Nightingale, H. I., \& Bianchi, W. C. (1980). Well-Water Quality Changes Correlated with Well Pumping Time and Aquifer Parameters-Fresno, California. Groundwater, 18(3), 274-280. https://doi.org/10.1111/j.1745-6584.1980.tb03399.x

Noel, J. E., Gardner, B. D., \& Moore, C. V. (1980). Optimal regional conjunctive water management. American Journal of Agricultural Economics, 62(3), 489-498. https://doi.org/10.2307/1240203

Norra, S., Berner, Z. A., Agarwala, P., Wagner, F., Chandrasekharam, D., \& Stüben, D. (2005). Impact of irrigation with as rich groundwater on soil and crops: a geochemical case study in West Bengal Delta Plain, India. Applied Geochemistry, 20(10), 1890-1906. https://doi.org/10.1016/j.apgeochem.2005.04.019

Pal, T., Mukherjee, P. K., \& Sengupta, S. (2002). Nature of arsenic pollutants in groundwater of Bengal basin-a case study from Baruipur area, West Bengal, India. Current Science, 82(5), 554-561.

Pfeiffer, L., \& Lin, C.-Y. C. (2012). Groundwater pumping and spatial externalities in agriculture. Journal of Environmental Economics and Management, 64(1), 16-30. https://doi.org/10.1016/j.jeem.2012.03.003 
Polizzotto, M. L., Harvey, C. F., Li, G., Badruzzman, B., Ali, A., Newville, M., ...\& Fendorf, S. (2006). Solid-phases and desorption processes of arsenic within Bangladesh sediments. Chemical Geology, 228(1-3), 97-111. https://doi.org/10.1016/j.chemgeo.2005.11.026

Polya, D., \&Charlet, L. (2009). Rising arsenic risk?. Nature Geoscience, 2(6), 383-384. https://doi.org/10.1038/ngeo537

Postma, D., Larsen, F., Hue, N. T. M., Duc, M. T., Viet, P. H., Nhan, P. Q., \& Jessen, S. (2007). Arsenic in groundwater of the Red River floodplain, Vietnam: controlling geochemical processes and reactive transport modeling. Geochimica et Cosmochimica Acta, 71(21), 50545071. https://doi.org/10.1016/j.gca.2007.08.020

Provencher, B., \& Burt, O. (1993). The externalities associated with the common property exploitation of groundwater. Journal of Environmental Economics and Management, 24(2), 139-158. https://doi.org/10.1006/jeem.1993.1010

Punshon, T., Jackson, B. P., Meharg, A. A., Warczack, T., Scheckel, K., \& Guerinot, M. L. (2017). Understanding arsenic dynamics in agronomic systems to predict and prevent uptake by crop plants. Science of the Total Environment, 581, 209-220. https://doi.org/10.1016/j.scitotenv.2016.12.111

Radloff, K. A., Zheng, Y., Michael, H. A., Stute, M., Bostick, B. C., Mihajlov, I., ...\& Schlosser, P. (2011). Arsenic migration to deep groundwater in Bangladesh influenced by adsorption and water demand. Nature Geoscience, 4(11), 793-798. https://doi.org/10.1038/ngeo1283

Rains, M. C. (2003). The Role of Groundwater in Resource Conservation Efforts. Conservation Biology, 17(3), 933-934. https://doi.org/10.1046/j.1523-1739.2003.t01-1-01733.x

Raquel, S., Ferenc, S., Emery Jr, C., \& Abraham, R. (2007). Application of game theory for a groundwater conflict in Mexico. Journal of Environmental Management, 84(4), 560-571. https://doi.org/10.1016/j.jenvman.2006.07.011

Ravenscroft, P., Burgess, W. G., Ahmed, K. M., Burren, M., \& Perrin, J. (2005). Arsenic in groundwater of the Bengal Basin, Bangladesh: Distribution, field relations, and hydrogeological setting. Hydrogeology Journal, 13(5-6), 727-751.

https://doi.org/10.1007/s10040-003-0314-0

Ripl, W. (1992). Management of water cycle: An approach to urban ecology. Water Quality Research Journal, 27(2), 221-238. https://doi.org/10.2166/wqrj.1992.016 
Rodell, M., Velicogna, I. \& Famiglietti, J. (2009). Satellite-based estimates of groundwater depletion in India. Nature, 460, 999-1002. https://doi.org/10.1038/nature08238

Roychowdhury, T., Tokunaga, H., Uchino, T., \& Ando, M. (2005). Effect of arseniccontaminated irrigation water on agricultural land soil and plants in West Bengal, India. Chemosphere, 58(6), 799-810.https://doi.org/10.1016/j.chemosphere.2004.08.098

Saha, G. C., Ali, M. A. (2006). Dynamics of arsenic in agricultural soils irrigated with arsenic contaminated groundwater in Bangladesh. Science of The Total Environment,379(2-3):180189. https://doi.org/10.1016/j.scitotenv.2006.08.050

Sahu, P., \&Sikdar, P. K. (2017). Effect of pumping on hydrologic system of a young satellite city in south Bengal Basin through numerical modelling: past, present and future. Sustainable Water Resources Management, 3(3), 321-341. https://doi.org/10.1007/s40899-017-0098-3

Sahu, P., Michael, H. A., Voss, C. I., \& Sikdar, P. K. (2013). Impacts on groundwater recharge areas of megacity pumping: analysis of potential contamination of Kolkata, India, water supply. Hydrological Sciences Journal, 58(6), 1340-1360. https://doi.org/10.1080/02626667.2013.813946

Salazar, R., Stone, J., Yakowitz, D., \& Slack, D. (2005). Multicriteria analysis in an irrigation district in Mexico. Journal of Irrigation and Drainage Engineering, 131(6), 514-524. https://doi.org/10.1061/(ASCE)0733-9437(2005)131:6(514)

Sarker, M. H., Akter, J., \& Rahman, M. M. (2013). Century-scale dynamics of the Bengal delta and future development. Proceedings on International Conference on Water and Flood Management, Dhaka, Bangladesh, 91-104.

Schmidt, K. (2007).UCSC Hydrogeologist provides expert advice on Pajaro Valley's water supply. U.C. SANTACRUZ (UCSC). http://www.ucsc.edu/news_events/text.asp?pid=1759

Schmidt, K. D. (1977). Water quality variations for pumping wells. Groundwater, 15(2), 130137. https://doi.org/10.1111/j.1745-6584.1977.tb03157.x

Scott, C. A., \& Shah, T. (2004). Groundwater overdraft reduction through agricultural energy policy: insights from India and Mexico. International Journal of Water Resources Development, 20(2), 149-164.https://doi.org/10.1080/0790062042000206156

Sengupta, M. K., Mukherjee, A., Hossain, M. A., Ahamed, S., Rahman, M. M., Lodh, D., ...\& Saha, K. C. (2003). Groundwater arsenic contamination in the Ganga-Padma-MeghnaBrahmaputra plain of India and Bangladesh. Archives of Environmental Health: An International Journal, 58(11), 701-702. https://doi.org/10.3200/AEOH.58.11.701-702 
Shah, T., Burke, J., Villholth, K. G., Angelica, M., Custodio, E., Daibes, F., ... \& Kendy, E. (2007). Groundwater: a global assessment of scale and significance. CGSpace: A Repository of Agricultural Research Ouput. https://hdl.handle.net/10568/36890

Shamsudduha, M., Chandler, R. E., Taylor, R. G., \& Ahmed, K. M. (2009). Recent trends in groundwater levels in a highly seasonal hydrological system: the Ganges-BrahmaputraMeghna Delta. Hydrol Earth Syst Sc, 13(12), 2373-2385. https://doi.org/10.5194/hess-132373-2009

Shamsudduha, M., Taylor, R. G., Ahmed, K. M., \& Zahid, A. (2011). The impact of intensive groundwater abstraction on recharge to a shallow regional aquifer system: evidence from Bangladesh. Hydrogeology Journal, 19(4), 901-916. https://doi.org/10.1007/s10040-0110723-4

Sherif, M. M., \& Singh, V. P. (2002). Effect of groundwater pumping on seawater intrusion in coastal aquifers. Journal of Agricultural and Marine Sciences [JAMS],7(2), 61-67. https://doi.org/10.24200/10.24200/jams.vol26iss1pp1-12

Sikdar, P. K., \& Chakraborty, S. (2008). Genesis of arsenic in groundwater of North Bengal Plain using PCA: a case study of English Bazar Block, Malda district, West Bengal, India. Hydrological Processes: An International Journal, 22(12), 1796-1809. https://doi.org/10.1002/hyp.6742

Sikdar, P. K., Ghosal, U., \& Chakraborty, S. (2018). Groundwater modeling to understand the impact of pumping in the deep Late Pleistocene aquifers of the western Bengal Basin on arsenic migration. Arabian Journal of Geosciences, 11(24), 795.

Sikdar, P. K., Sarkar, S. S., \& Palchoudhury, S. (2001). Geochemical evolution of groundwater in the Quaternary aquifer of Calcutta and Howrah, India. Journal of Asian Earth Sciences, 19(5), 579-594. https://doi.org/10.1016/S1367-9120(00)00056-0

Sophocleous, M. (2000). From safe yield to sustainable development of water resources-the Kansas experience. Journal of Hydrology, 235(1-2), 27-43. https://doi.org/10.1016/S00221694(00)00263-8

Stute, M., Zheng, Y., Schlosser, P., Horneman, A., Dhar, R. K., Datta, S., ... \& Van Geen, A. (2007). Hydrological control of As concentrations in Bangladesh groundwater. Water Resources Research, 43(9). https://doi.org/10.1029/2005WR004499

Susheela, A. K. (1999). Fluorosis management programme in India. Current Science, 77(10), 1250-1256. http://repository.ias.ac.in/64544/1/64544.pdf 
Swartz, C. H., Blute, N. K., Badruzzman, B., Ali, A., Brabander, D., Jay, J., .. \& Harvey, C. F. (2004). Mobility of arsenic in a Bangladesh aquifer: Inferences from geochemical profiles, leaching data, and mineralogical characterization. Geochimica et Cosmochimica Acta, 68(22), 4539-4557. https://doi.org/10.1016/j.gca.2004.04.020

Tiwari, V. M., Wahr, J., \& Swenson, S. (2009). Dwindling groundwater resources in northern India, from satellite gravity observations. Geophysical Research Letters, 36(18). https://doi.org/10.1029/2009GL039401

Tularam, G. A., \& Krishna, M. (2009). LONG TERM CONSEQUENCES OF GROUNDWATER PUMPING IN AUSTRALIA: A REVIEW OF IMPACTS AROUND THE GLOBE. Journal of Applied Sciences in Environmental Sanitation, 4(2). https://research-

repository.griffith.edu.au/bitstream/handle/10072/29294/58579_1.pdf;sequence=1

Tweed, S., Celle-Jeanton, H., Cabot, L., Huneau, F., De Montety, V., Nicolau, N., ... \& Leblanc, M. (2018). Impact of irrigated agriculture on groundwater resources in a temperate humid region. Science of the Total Environment, 613, 1302-1316.

https://doi.org/10.1016/j.scitotenv.2017.09.156

Ullah, S. M. (1998). Arsenic contamination of groundwater and irrigated soils of Bangladesh. In International conference on arsenic pollution of groundwater in Bangladesh: causes, effects and remedies, 1998. Dhaka: Dhaka Community Hospital. https://ci.nii.ac.jp/naid/10029236000/

Van Geen, A., Zheng, Y., Cheng, Z., He, Y., Dhar, R. K., Garnier, J. M., ... \& Ahmed, K. M. (2006). Impact of irrigating rice paddies with groundwater containing arsenic in Bangladesh. Science of the Total Environment, 367(2-3), 769-777. https://doi.org/10.1016/j.scitotenv.2006.01.030

Villholth, K. G. (2013). Groundwater irrigation for smallholders in Sub-Saharan Africa-a synthesis of current knowledge to guide sustainable outcomes. Water International, 38(4), 369-391. https://doi.org/10.1080/02508060.2013.821644

Wang, Y., Xiao, D., Li, Y., \& Li, X. (2008). Soil salinity evolution and its relationship with dynamics of groundwater in the oasis of inland river basins: case study from the Fubei region of Xinjiang Province, China. Environmental Monitoring and Assessment, 140(1-3), 291-302. http://dx.doi.org/10.1007\%2Fs10661-007-9867-z

Wemer, A. H., \& Gleeson, T. (2012) Regional strategies for the accelerating global problem of groundwater depletion. Nature Geoscience, 5, 853-861. https://doi.org/10.1038/ngeo1617 
Werner, A. D., Ward, J. D., Morgan, L. K., Simmons, C. T., Robinson, N. I., \& Teubner, M. D. (2012). Vulnerability indicators of sea water intrusion. Groundwater, 50(1), 48-58. https://doi.org/10.1111/j.1745-6584.2011.00817.x

Whittemore, D. O., McGregor, K. M., \&Marotz, G. A. (1989). Effects of variations in recharge on groundwater quality. Journal of Hydrology, 106(1-2), 131-145. https://doi.org/10.1016/0022-1694(89)90170-4

Williams, P. N., Islam, M. R., Adomako, E. E., Raab, A., Hossain, S. A., Zhu, Y. G., .. \& Meharg, A. A. (2006). Increase in rice grain arsenic for regions of Bangladesh irrigating paddies with elevated arsenic in groundwaters. Environmental Science \&Technology, 40(16), 4903-4908. https://doi.org/10.1021/es060222i

Wilson, L. C., \& Rouse, J. V. (1983). Variations in water quality during initial pumping of monitoring wells. Groundwater Monitoring \& Remediation, 3(1), 103-109. https://doi.org/10.1111/j.1745-6592.1983.tb00870.x

Wingo, A. (2001). Impacts of Groundwater Overdraft. Wingolog. http://wingolog.org/writings/water/html/node35.html

Wright, J. F., \& Berrie, A. D. (1987). Ecological effects of groundwater pumping and a natural drought on the upper reaches of a chalk stream. Regulated Rivers: Research \& Management, 1(2), 145-160. https://doi.org/10.1002/rrr.3450010205

WWAP. (2003). Water for people water for life. World Water Development report. The United Nations. Sustainable Development UN.

https://sustainabledevelopment.un.org/content/documents/WWDR_english_129556e.pdf

Xie, X., Wang, Y., Li, J., Yu, Q., Wu, Y., Su, C., \& Duan, M. (2015). Effect of irrigation on Fe (III)-SO42- redox cycling and arsenic mobilization in shallow groundwater from the Datong basin, China: evidence from hydrochemical monitoring and modeling. Journal of Hydrology, 523, 128-138. https://doi.org/10.1016/j.jhydrol.2015.01.035

Xie, X., Wang, Y., Su, C., Li, J., \& Li, M. (2012).Influence of irrigation practices on arsenic mobilization: evidence from isotope composition and $\mathrm{Cl} / \mathrm{Br}$ ratios in groundwater from Datong Basin, northern China. Journal of Hydrology, 424-425, 37-47. https://doi.org/10.1016/j.jhydrol.2011.12.017

Xu, X. Y., McGrath, S. P., Meharg, A. A., \& Zhao, F. J. (2008). Growing rice aerobically markedly decreases arsenic accumulation. Environmental Science \&Technology, 42(15), 5574-5579. https://doi.org/10.1021/es800324u 
Zektser, S., Loáiciga, H. A., \& Wolf, J. T. (2005). Environmental impacts of groundwater overdraft: selected case studies in the southwestern United States. Environmental Geology, 47(3), 396-404. https://doi.org/10.1007/s00254-004-1164-3

Zheng, Y., Van Geen, A., Stute, M., Dhar, R., Mo, Z., Cheng, Z., ...\&Steckler, M. (2005). Geochemical and hydrogeological contrasts between shallow and deeper aquifers in two villages of Araihazar, Bangladesh: Implications for deeper aquifers as drinking water sources. Geochimica et Cosmochimica Acta, 69(22), 5203-5218. 